\title{
Contagious Ecthyma Virusu (ORF) İzolasyonunda FLK-BLV-044 Hücre Kültürünün Kullanılması
}

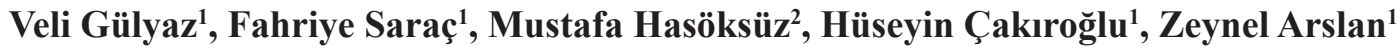 \\ ${ }^{1}$ Pendik Veteriner Kontrol Enstitüsü 34890, İstanbul \\ ${ }^{2}$ İstanbul Üniversitesi Veteriner Fakültesi Viroloji ABD, Avcllar, İstanbul
}

Geliş Tarihi / Received: 19.02.2016, Kabul Tarihi / Accepted: 29.05.2016

\begin{abstract}
Özet: Bu çalışma, FLK-BLV-044 hücre kültürünün Contagious Ecthyma (CE) enfeksiyonuna yakalanmış kuzu ve oğlaklardan orf virusunun izolasyonunda ilk kez kullanılması amacıyla gerçekleştirilmiştir. Klinik olarak CE lezyonlarına sahip 4 oğlak ve 2 kuzuya ait dudak dokusundan hazırlanan inokulumlar PCR testi ile orf virusuna ait nükleik asitlerin varlığı yönünden test edildi. Örneklerden monolayer FLK-BLV-044 hücre kültürlerine ekimler gerçekleştirildi. Yapılan hücre kültürü ekimlerinin 2. pasajında hücre yuvarlaklaşması ile karekterize sitopatik efekt (CPE) odaklarının oluştuğu saptandı. PCR testi ile izole edilen virusların orf virusu olduğu, üreyen virusların titrelerinin 3 oğlak ve 1 kuzu izolatında DKID $_{50} 10^{5,5}$ ve 1 kuzu ve 1 oğlak izolatında $10^{5,0} / \mathrm{ml}$ olduğu, yapılan histopatolojik boyamalarda üreyen virusların intrasitoplazmik inkluzyon cisimleri oluşturduğu saptand1. Sonuç olarak, sürekli üretilebilir karakterde olan FLK-BLV-044 hücre kültürünün $\mathrm{CE}$ enfeksiyonuna yakalanmış hayvanlardan orf virusunun izolasyonunda kullanılabileceği ortaya konulmuştur.
\end{abstract}

Anahtar kelimeler: Contagious ecthyma, hücre kültürü, izolasyon, orf virus

\section{The Use of FLK-BLV-044 Cell Culture for Isolation of Contagious Ecthyma Virus (Orf)}

\begin{abstract}
The aim of this study was to use of FLK-BLV-044 cell culture for isolation of orf viruses from lambs and kids infected with contagious ecthyma virus. For this purpose, the existence of nucleic acid of orf virus was analyzed by PCR test from inoculum prepared from lips clinicaly infected 4 kids and 2 lambs. Each of the samples were inoculated into FLK-BLK-044 monolayer cell cultures. Cytopathogenic effect (CPE) characterized by rounding of the cells were seen in the second passage of the cell cultures. Isolated viruses were idendified as orf virus by PCR test. The titer of viruses were found as $10^{5.5} / \mathrm{ml} \mathrm{TCID}_{50}$ for 3 kids and 1 lamb strains, $10^{5.0} / \mathrm{ml}$ for 1 goat and 1 lamb strains. Intracytoplasmic inclusion bodies were detected in infected cells with HxE staining. In conclusion, it was represented that the FLKBLV-044 cell cultures, propagated permanently, can be used for isolation of orf virus from infected materials obtained from kids and lambs.
\end{abstract}

Key words: Cell culture, Contagious Ecthyma, isolation, orf virus

\section{Giriş}

Contagious ecthyma (CE) veya contagious pustular dermatitis olarak bilinen orf hastalığ 1 koyun ve keçilerde özellikle kuzu ve oğlaklarda dudak, burun çevresi, ağız mukozası, meme ve meme uçlarında yaygin olarak görülen nonsistemik eruptif deri hastalığıdır $[10,14]$. Hastalık etkeni Poxviridae famiyasının Parapoxvirus genusunda yer alan orf virusudur [14]. CE enfeksiyonunun teşhisinde Elektron mikroskopi, virus izolasyonu, Serum Nötralizasyon Testi, Komplemet Fiksasyon Testi, Agar Jel Immuno Diffüzyon, İmmunperoksidaz, Floresan Antikor
Tekniği, ELISA ve Polimeraz Zincir Reksiyonu (PCR) Testleri kullanılmaktadır $[5,11,15,18]$. Orf virusunun izolasyonu amaciyla primer kuzu ve oğlak hücre kültürleri ile birlikte vero, fetal lamb lung (CSL-503), BHK, MDBK, MDCK gibi devamlı üretilebilen hücre kültürleri kullanılmaktadır $[1,4,8,16,17]$.

$\mathrm{Bu}$ çalışma, $\mathrm{CE}$ enfeksiyonuna yakalanmış kuzu ve oğlaklardan orf virusunun izolasyonunda sürekli pasajlanabilir cell line FLK-BLV-044 hücre kültürünün kullanılması amacıyla gerçekleştirilmiştir. 


\section{Materyal ve Metot}

\section{Enfekte doku örnekleri}

Çalışmada kullanılan enfekte dudak derisi örnekleri klinik olarak CE lezyonlarına sahip 1-3 aylık 4 oğlak ve 2 kuzudan elde edildi.

\section{Hücre kültürü}

CE şüpheli doku örneklerinden orf virusu izolasyonu amaciyla kullanılan FLK-BLV-044 (ovine embrional kidney cells) (DSMZ No: ACC 153) Almanya DSMZ hücre kültürü koleksiyonundan temin edildi.

\section{İnokulum hazırlanması}

Kuzu ve oğlaklardan elde edilen lezyonlu dudak deri örnekleri havan içinde ezilerek virus üretme vasatı içinde homojenatlar hazırlandı. Örnekler 3000 rpm'de 20 dakika santrifüj edildi ve $0,45 \mu \mathrm{m}$ filtrelerden geçirildi [9].

\section{Doku örneklerinde orf virusunun tespiti}

Doku homojenatlarından DNA ekstraksiyonu amaciyla ticari genomik DNA purifikasyon kiti (Promega) kullanıldı. DNA peletleri $50 \mathrm{ml}$ distile su içinde topland 1 ve kullanılincaya kadar $-20{ }^{\circ} \mathrm{C}$ 'de sakland1. Orf virusunun identifikasyonu amaciyla Inoshima ve ark. (2000) tarafindan bildirilen semi-nested PCR metodu kullanıldı.[13]

\section{Virus izolasyonu}

Flasklarda \%10 FCS içeren Dulbecco's MEM/ Ham's F-12 (Biochrom) vasatı ile monolayer hücre kültürü hazırlandı (Şekil 2). Hazırlanan örnekler FLK-BLV-044 hücre kültürüne inokule edildi. Hücre kültürleri $37^{\circ} \mathrm{C}$ 'de, $\% 5 \mathrm{CO}_{2}$ 'li etüvde inkubasyona birakıldı. Her gün inverted mikroskopta sitopatik efekt (CPE) oluşumu yönünden kontrolleri gerçekleştirildi. Hücre kültürlerinde CPE oluşumlar1 gözlenene kadar 5 günde bir kör pasajlar yapıldı ve \%75 CPE görülen hücre kültürleri $3 \mathrm{kez}$ dondurulup çözdürüldü. Santrifüj ile temizlenen süpernatantlar kullanılıncaya kadar $-80^{\circ} \mathrm{C}$ 'de muhafaza edildi $[8,9]$.

\section{Virus titrasyonu}

Hücre kültüründe CPE oluşturarak üreyen orf viruslarının titrasyonu FLK-BLV-044 hücre kültüründe
Buddle ve ark. [2,3] tarafindan bildirilen metotla gerçekleştirildi. Santrifüj işlemi 3000 rpm'de 20 dakika yapılarak hücre kalıntılarından temizlenen virus süspansiyonunun DMEM/Ham's-F12 vasat1 içinde 10 katlı dilüsyonu yapıldı. Her dilüsyondan 96 gözlü pleytlerin 4 gözüne 100'er $\mu$ l kondu ve üzerine $1 \times 10^{4} / \mathrm{ml}$ hücre süspansiyonundan $100^{\prime} \mathrm{er}$ $\mu 1$ eklendi. Pleytler $37^{\circ} \mathrm{C}$ 'de, $\% 5 \mathrm{CO}_{2}$ 'li etüvde inkubasyona bırakıldı ve pleytler CPE oluşumları yönünden 5-7 gün süreyle gözlendi. TCID $_{50}$ değerleri Karber Metodu ile saptandi.

\section{Hücre kültürlerinde virus üremesinin tespiti}

\section{Hücre kültürlerinin histolojik muayenesi}

İzole edilen orf viruslarının hücre kültüründe üremesi esnasında oluşturduğu inkluzyon cisimciğinin saptanması amaciyla orf virusu inokulasyonu yapılan FLK-BLV-044 lamel hücre kültüründe Hematoksilen-Eozin (H\&E) boyama gerçekleştirildi [7].

\section{Orf virusu varlığının saptanması}

Toplanan klinik örnekler ve pozitif kontrolden, viral DNA'nın ekstraksiyonu için, DNAeasy Blood and Tissue Kit (QIAGEN) üretici talimatlarına göre kullanıldi.

\section{PCR reaksiyonu}

PCR reaksiyonu için Inoshima ve ark. (2000) tarafindan bildirilen yöntem uygulandı. PCR ürününün çoğaltılmasında, elde edilen viral DNA'dan 1 mikrogram, toplam $50 \mu$ l reaksiyon miktarı için, 0,2 $\mathrm{mM}$ her bir primerden (PPP-1 ve PPP-4), $200 \mathrm{mM}$ dNTP, 10 mM Tris-HCl (pH 8,3), 50 mM KCl, 1,5 $\mathrm{mM} \mathrm{MgCl} 2$ ve $1 \mathrm{U}$ Taq DNA polimeraz (Fermentas) kullanıld1.

PCR reaksiyonu için 1sı döngü cihazı (Techne TC-412 Thermal Cycler), $95^{\circ} \mathrm{C}^{\prime} \mathrm{de} 9 \mathrm{dk}$ 'y1 takiben, $94^{\circ} \mathrm{C}^{\prime} \mathrm{de} 1 \mathrm{dk}, 55^{\circ} \mathrm{C}^{\prime} \mathrm{de} 1 \mathrm{dk}$ ve $72^{\circ} \mathrm{C}^{\prime} \mathrm{de} 1 \mathrm{dk}$ olacak şekilde 30 siklus şeklinde ayarlandı. Semi nested PCR, ilk reaksiyon sonucu elde edilen $5 \mu$ PCR ürünü ile aynı reaksiyon şartlarında PPP-3 ve PPP-4 primerleri kullanılarak tekrarland1 [13]. PCR ürünlerinin görüntülenmesi, $0,5 \mu \mathrm{g} / \mathrm{ml}$ etidyum bromid içeren \%1'lik agaroz jelin elektroforezi ile gerçekleştirildi. 


\section{Bulgular}

Klinik olarak CE enfeksiyonu belirtileri gösteren 4 oğlak ve 2 kuzu numunesinden hazırlanan homojenatların semi-nested PCR testi ile 235 bp büyüklüğünde amplikonlar elde edildi (Şekil 1). Virus izolasyonu amacıyla hücre kültürüne yapılan inokulasyonlar sonucu hücre kültürlerinin 2. pasajlarında virus üremesine bağlı CPE odaklarının, inkubasyonun 3. gününden itibaren ortaya çıktığ1 ve 5. günde \%90’a ulaștığı gözlendi (Şekil 3). Üreyen virusların titreleri 3 oğlak ve 1 kuzu izolatında DKID $_{50} 10^{5,5}$ / $\mathrm{ml}$ ve $1 \mathrm{kuzu}$ ve 1 oğlak izolatında $10^{5,0} / \mathrm{ml}$ olarak belirlendi. FLK-BLV-044 hücre kültürlerinde izole edilen 6 izolatın yapılan semi-nested PCR ile orf virusu olduğu (SSekil 3), lamel hücre kültürlerinin histopatolojik boyamalarında üreyen virusların intrasitoplazmik inkluzyon cisimcikleri oluşturduğu tespit edildi (Şekil 4).

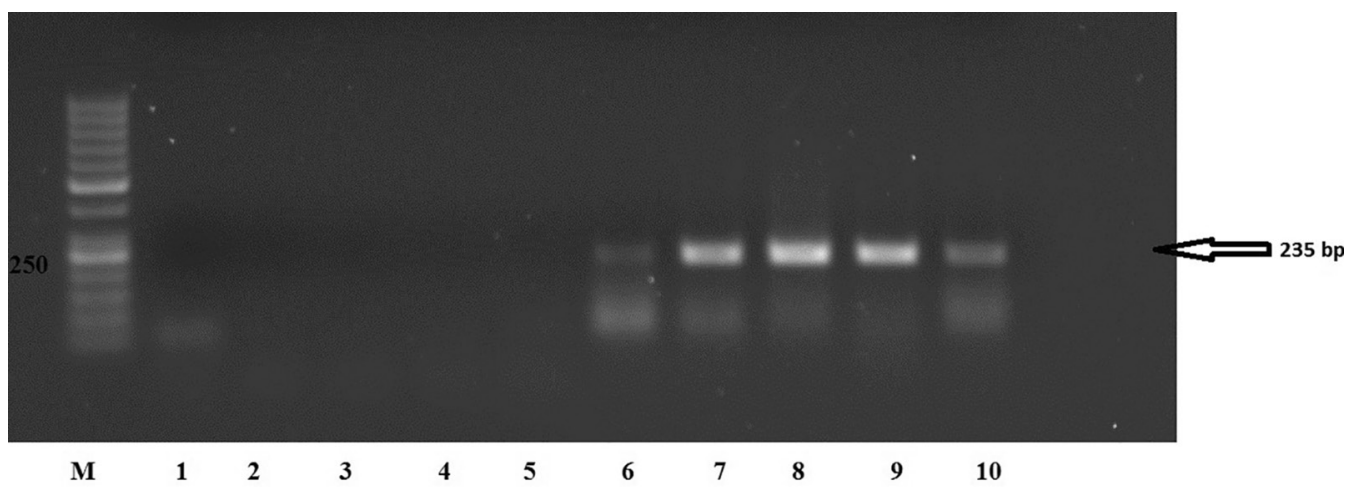

Şekil 1. M: Marker (50 bp), 1-5: 1. PCR (PPP1-PPP4), 6-10: Semi-nested PCR (PPP3-PPP4)

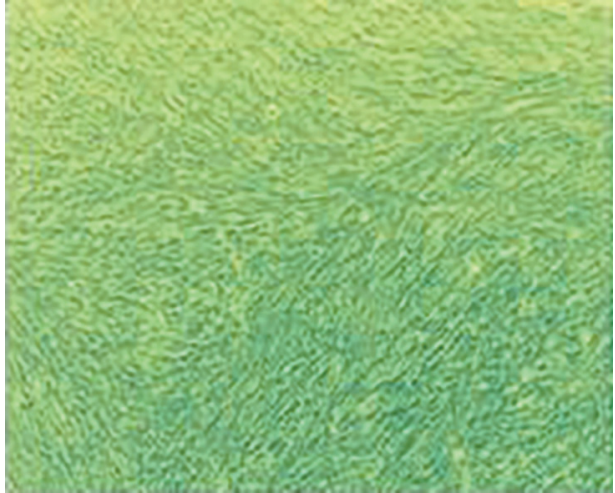

Şekil 2. FLK-BLV-044 hücre kültürü

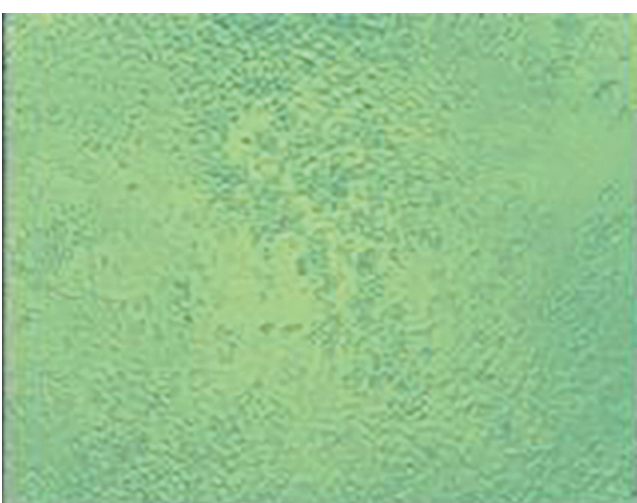

Şekil 3. Orf virusunun CPE oluşumları

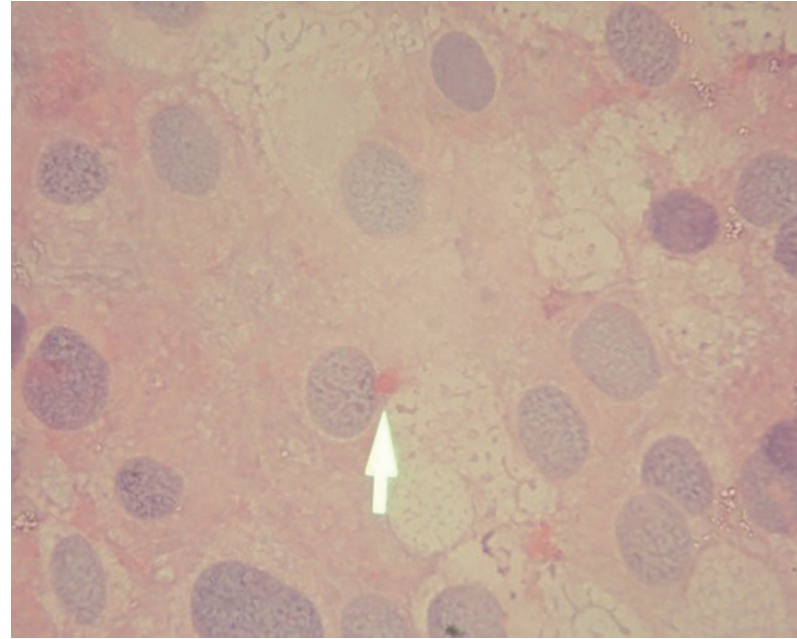

Şekil 4. FLK-BLV-044 hücre kültüründe orf virusuna ait intrasitoplazmik inkluzyon cisimciği

\section{Tartışma}

Koyun ve keçilerde CE enfeksiyonunun teşhisi amaciyla son yıllarda PCR kullanılırken, virus izolasyonu metodunun zaman alması ve zahmetli olmas1 nedeniyle yaygin olarak kullanılmamaktadir. Ancak, orf virusunun gerek moleküler gerekse aşı-patojenite çalışmaları amacıyla izolasyon ça- 
lışmalarına ihtiyaç duyulmaktadır. Koyun ve keçilerde orf virusunun izolasyonu amaciyla primer ve sürekli hücre kültürleri yaygın olarak kullanılmaktadır $[2,3,6,8,12]$. Primer hücre kültürleri virus izolasyonları için her ne kadar uygun ise de birçok dezavantaja sahiptirler. Primer hücre kültürlerinin düzenli aralıklarla hayvan dokularından hazırlanmas1, karekterize edilmesi ve viral kontaminantlar yönünden test edilmeleri de gerekmektedir. Sürekli üretilebilen hücreler bu dezavantajlara sahip olmadıkları gibi likit nitrojende kullanılıncaya kadar yıllarca saklanabilirler [16].

Orf virusunun izolasyonu amaciyla yapılan diğer çalışmalarda primer ve sürekli hücre kültürlerinde elde edilen virus titreleri $\mathrm{DKID}_{50} 10^{4,5}-10^{7,5} /$ ml olduğu ve virusun 2-3 kör pasaj1 takiben hücre kültürlerinde yuvarlaklaşma ile karakterize CPE oluşturduğu bildirilmiştir [3,6,8,12] Bu çalışmada, orf virusunun FLK-BLV-044 hücre kültüründe 2. kör pasajda $\mathrm{DKID}_{50} 10^{5,5}-10^{5,0} / \mathrm{ml}$ titrelerde hücre yuvarlaklaşması ile karakterize üremesinin diğer çalışmalarda elde edilen sonuçlarla benzer olduğu görülmüştür.

Sonuç olarak, bu çalışma ile devamlı üretilebilir (permanent cell line) hücre hattı olan FLKBLV-044 hücre kültürünün orf virusu izolasyonu amacıyla kullanılabileceği ortaya konulmuştur.

\section{Kaynaklar}

1. Abu Elzein EME, Housavi FMT, (2009). Drastic cutaneous multi-focal orf infection in goats, causing severe dysfunctioning. Rev Sci Tech Off Int Epiz, 28(3),1025-1029.

2. Buddle BM, Dellers RW, Schuring GG, (1984 a). Heterogenecity of contagious ecthyma virus isolates. Am J Vet Res, 45(1), 75-79.

3. Buddle BM, Dellers RW, Schuring G. G, (1984 b). Contagious echtyma virus-vaccination failures. Am. J. Vet. Res, 45(2), 263-266.

4. Coates JW, Haff S, (1990). Contagious ecthyma: An unusual distribution of lesions in goats. Can Vet J, 31, 209-210.
5. Çabalar M, Voyvada H, Sekin S, (1996). Van yöresinde bir sürüde ecthyma contagious (Orf) olgusu. Ankara Üniv Vet Fak Derg, 43,45-51.

6. De la Concha-Bermejillo A, Guo J, Zhang Z, Waldron D, (2003). Severe persistant orf in young goats. J Vet Diagn Invest, 15, 423-431.

7. Ekicioğlu G, Özkan N, Şalvaazar E, (2005). HematoksilenEozin (hematoxylin-eosin) (H\&E). Aegean Pathology Journal, 2, 58-61.

8. Ergin H, Köklü A, (1974). Ektima virusunun doku kültürlerinde pasajı ve antijenik özelliklerinin incelenmesi. Pendik Vet Mikrobiyol Derg, 6(2),12-20.

9. Guo J, Rasmussen J, Wünschmann A, De la ConchaBermejillo A, (2004). Genetic characterization of orf viruses isolated from various ruminant species of a zoo. Vet Microbiol, 99, 81-92.

10. Hawkins CD, Ellis TM, Davis MK, Peet RL, Parkinson J, (1991). An unusual outbreak of contagious ovine ecthyma. Aust Vet J, 68, 210-211.

11. Hooser SB, Scherbo G, Morin DE, Whiteley HE, (1989). A typical contagious ecthyma in a sheep after extensive cutaneous thermal injury. Jaoumo, 195(9), 1255-1256.

12. Housawi FMT, Abu Elzein EME, Amin MM, Al Afaleg AI, (1991). Contagious pustular dermatitis (orf) infection in sheep and goats in Saudi Arabia. Vet Rec, 128, 550-551.

13. Inoshima Y, Morooka A, Sentsui H, (2000). Detection and diagnosis of parapoxvirus by polimerase chain reaction. Journal of Virological Methods, 84, 201-208.

14. Mondal B, Bera AK, Hosamani M, Tembhurne PA, Bandyopadhyay SK, (2006). Detection of virus from an outbreak in goats and its genetic relation with other Parapoxviruses. Vet Res Commun, 30, 531-539.

15. Nettleton PF, Gilray JA, Yirrell DL, Scott GR, Reid HW, (1996). Natural transmission of orf virus from clinically normal ewes to orf-naive sheep. Vet Record, 139, 364-366.

16. Pye D, (1989). Cell lines for growth of sheep viruses. Aust Vet J, 66(7), 231-232.

17. Sanchez RL, Hebert A, Lucia H, Swedo J, (1985). A case report with histologic, electron microscopic and immunoperoxidase studies. Arch Pathol La Med, 109, 166-170.

18. Zhang K, Lu Z, Shang Y, Zhergld, Jin Y, He J, Liu , (2010). Diagnosis and phylogenetic analysis of orf virus from goats in China. Virology Journal, 7, 78. 